Synthesis, part of a Special Feature on A Social-Ecological Analysis of Diversified Farming Systems: Benefits, Costs, Obstacles, and Enabling Policy Frameworks

\title{
Nurturing Diversified Farming Systems in Industrialized Countries: How Public Policy Can Contribute
}

\author{
$\underline{\text { Alastair Iles }}^{1}$ and $\underline{\text { Robin Marsh }}^{2}$
}

\begin{abstract}
If diversified farming systems (DFS) are to thrive again in the United States, policies and preferences must evolve to reward the environmental and social benefits of sustainable farming and landscape management. Compared with conventional agricultural policies, policies aiding ecological diversification are underdeveloped and fragmented. We consider several examples of obstacles to the adoption and spread of diversified farming practices in the U.S. industrialized agricultural system. These include the broader political economic context of industrialized agriculture, the erosion of farmer knowledge and capacity, and supply chain and marketing conditions that limit the ability of farmers to adopt sustainable practices. To overcome these obstacles and nurture DFS, policy makers, researchers, industry, farmers, consumers, and local communities can play pivotal roles to transform agricultural research, develop peer-to-peer learning processes, support the recruitment and retention of new farmers through access to credit and land, invest in improved agricultural conservation programs, provide compensation for provision of ecological services in working landscapes, and develop links to consumer and institutional markets.
\end{abstract}

Key Words: conservation programs; direct marketing; diversified farming; farmer knowledge; obstacles; public policy

\section{INTRODUCTION}

Diversified farming systems (DFS) dominated food production in the United States and other developed countries before industrialized agriculture systems progressively displaced them from the late 19th century onward (Walker 2006). In creating DFS, farmers use practices that intentionally include functional biodiversity at multiple spatial and temporal scales to maintain ecosystem services that provide critical inputs to agriculture (Kremen et al. 2012). These farmers often use practices grounded in traditional and agroecological knowledge. If DFS are to thrive again in the USA, policies and preferences must evolve to reward the ecological and social benefits of sustainable farming and landscape management. Farmers already dedicated to sustainable practices (e.g., organic and eco-agriculture farms) need robust support, and conventional farming landscapes need policy, regulatory, and market signals to shift progressively from degradation to diversification.

Industrialized agricultural systems such as those in the USA take a spectrum of forms worldwide, reflecting diverging geographic, historical, climatic, ecological, economic, and social contexts. In general, however, they simplify ecosystems, use methods such as monocultures, specialization, and non-ecologically generated inputs, and aim to maximize crop or livestock profitability. In some cases, industrialized farms or landscapes may already incorporate a few sustainable practices because of farmer interest or government incentives. Nonetheless, industrialized agriculture systems share many significant environmental and social impacts (see Kremen et al. 2012). They also reflect deeper political, economic, and cultural conditions that obstruct the spread of DFS, including the broader political economy of agriculture, global trade in cheap food commodities, the erosion of farmer capabilities to practice diversified farming based on agroecological methods, and regulatory, land use, and supply-chain disincentives for farmers to adopt DFS practices.

Conversely, connecting public policies, political institutions, and social movements can help increase ecological sustainability and improve environmental and human health from farm households to regional scales (Kremen and Miles 2012). In general, researchers and practitioners have neglected the potential contribution of policy in expanding agroecology and DFS more widely (one exception is Buttel 2006). We review several examples of obstacles to scaled-up adoption of DFS that farmers and land managers face. We then review four sets of promising policies already being tested in the USA, with some examples also from Europe and Australia. We emphasize policies that would provide the missing knowledge, incentives, and market infrastructure needed to sustain DFS as inherently variable and site-specific systems at landscape scales.

\section{POLITICAL ECONOMY OBSTACLES}

Numerous obstacles exist to the revival and spread of DFS. Here, we focus on examples of obstacles that shape the systemic social conditions that affect whether and how farmers may adopt diversified practices. Most fundamentally, the broader socioeconomic and institutional context in which agriculture is carried out explains how deeply industrialized agriculture is entrenched as a system, making it difficult for alternative production systems to compete. Producers face mutually reinforcing incentives to increase outputs, expand 
their farm sizes, specialize in crops or livestock, remove ecological diversity, and use monocultures and chemical inputs (Buttel 2006). This trend persists despite clear evidence since the 1990s of declining yield growth rates per unit of land for wheat, maize, rice, and soybeans on mono-cropped fields (Alston et al. 2009). From the perspective of those promoting industrialized agriculture, the "alternative" agricultural paradigm - of producing multiple ecological, food, and social benefits to sustainably feed a projected 9 billion people by 2050-appears unrealistic.

Most significantly, the full environmental and social impacts of industrialized agriculture are not internalized in production cost accounting nor are they passed on to consumers (Pretty 1995, Buttel 2006). An illustrative example is the excess nutrient run-off in the U.S. Corn Belt and its impact on eutrophication and hypoxia in the Gulf of Mexico, endangering fisheries and fisher livelihoods (Carpenter 2008). Two major historical trends have driven this growing cost externalization in the USA. First, corporate interests came to dominate agricultural production through competition, concentration, distant ownership, and vertical integration from the 1940s onward (Levins 2000, Buttel 2006, Walker 2006). Farmers became more dependent on yield-increasing technologies and external inputs and ever larger landholdings to expand their production to survive the lower prices following World War II. As growers spent more of their incomes on production costs, they became increasingly vulnerable to input suppliers and agri-food businesses that were focused on keeping those costs high. Over the course of just one decade, farmers lost most of their retained income to the point where they earned only one cent per dollar spent on food in 1960 compared with 49 cents in 1949, improving to 16 cents by 2008 (Canning 2011). Farmers were not the only ones to suffer the effects of agriculture's industrialization. Environmental impacts proliferated, from habitat destruction, water pollution, to wildlife exposures to pesticides. Yet, with lengthening supply chains and urbanization, consumers and downstream processors became less aware of both farmer predicaments and environmental impacts, and less inclined to demand intervention by governments and industry (Buttel 2006).

Second, in the 1930s, the federal government began supporting farmers with direct payments, expanding these in the 1960s, in an attempt to maintain agricultural commodity prices domestically and to help farmers find new export markets in combination with international trade policies (Friedmann and McMichael 1989, Levins 2000). Certain industrial agricultural operations now receive a range of subsidies from governments through direct payments, tax deductions, research and development investments, irrigation, fossil fuel inputs, and agricultural extension (National Academy of Sciences (NAS) 2010). These subsidies encourage over-production of some foods in particular geographical regions, add to motivations for growing farm sizes and specialization, and require adoption of intensive farming methods (Faeth and Westra 1993, Pretty 1995). They have allowed agri-food companies to provide cheap processed foods from abundant supplies and increase their market power. Subsidies, as they have evolved in the USA (and in Europe until around 2003), have diverted government attention and resources away from considering how to promote ecological diversification more creatively, in contrast to the purported goals of land conservation and human health, which successive Farm Bills have promoted.

In the USA, the vast majority of commodity payments go to seven crops, including corn, wheat, rice, and cotton, based on land area and yield, or as top-up payments when market prices fall below the guaranteed "floor" price (Sumner et al. 2007). These crops are also exported overseas at low prices, undermining the ability of smallholders in developing countries to compete in the marketplace. Ironically, many of these smallholders currently practice DFS techniques. Farmers are not eligible to receive such payments if they produce vegetables, nuts, and fruits on their land counted as base acres, thus deterring diversified farming. Subsidies also go to a relatively small number of farmers, predominantly large producers concentrated in the Midwest and the South (Sumner et al. 2007). As of 2010, only $38 \%$ of American farmers received commodity supports, with the largest $10 \%$ of farmers collecting 74\% of the total. Between 1995 and 2010, the federal government paid $\$ 262$ billion in subsidies to the agricultural sector, with $\$ 107$ billion for commodity payments, $\$ 39$ billion for crop insurance, and only $\$ 35$ billion for conservation purposes ( $\$ 28$ billion for land retirement, $\$ 4$ billion for working farms; Environmental Working Group (EWG) 2011).

The apparent cheapness of food is also due to the monopolistic ability of agri-food companies to force farmers, workers, and rural communities to accept lower prices or incomes. In turn, growers must find ways to produce more cheaply, favoring the adoption of larger-scale technologies and larger farm sizes due to scales of economy (Levins 2000). Simultaneously, these companies require farmers to use packages of inputs that the companies themselves may also produce, including diesel, pesticides, and seeds, decreasing per unit production costs but creating externalities and locking farmers more deeply into industrialized production.

What, we may ask, is enabling this deep entrenchment of corporate power in the agri-food system? This power stems from a mutually reinforcing process of making agricultural policies and controlling supply chains. Over six decades in the USA, agricultural policies have favored larger-scale, intensive, increasingly concentrated production in grains, meats, and dairy, creating an established set of economically and politically powerful agri-food corporations, retailers, and large producers that strongly influence the political process 
through donations, lobbying, and market strength, furthering their advantages with each legislative cycle (Lyson 2004, Pollan 2006, Clapp and Fuchs 2009). These corporate actors have subsequently reshaped supply chains around their growing market power. It has become gradually more difficult to change the trajectory of agricultural policies, as seen in the relatively unchanged series of Farm Bills in the USA that continue to reflect a bias toward industrialized agriculture, but not impossible as seen in the changes in the Common Agricultural Policy in Europe that favor multi-functional production (Glebe 2007, Haniotis 2007).

Importantly, the agricultural sector is also permeated by power and resource inequalities among different groups of farmers. Most sales and income are generated by a relatively small number of farms. The vast majority of farms in the USA are family owned (90\%), with partnerships and non-familyowned corporations accounting for $8.5 \%$ of farms (United States Department of Agriculture National Agricultural Statistics Service (USDA-NASS) 2009, all statistics following). Family farms are relatively small in size and economic output (by industrialized standards): 54\% occupy less than 100 acres, with only $7.8 \%$ exceeding 1000 acres. Most farms earn net profits of less than $\$ 50,000$ yearly, with $59 \%$ making less than $\$ 10,000$ (part-time operations). Only $16 \%$ of U.S. farms earn over $\$ 100,000$. By contrast, the top $2 \%$ of the largest family and corporate farms by revenues generate 59\% of sales; ca. 35,000 farms with over \$1 million in sales produced 60\% of total food output in 2007. Most of these large farms benefit from commodity crop supports from the federal government, whereas small farms tend to rely more on their own resources, including off-farm employment. Due to the confluence of these factors, most U.S. farmers have fewer economic and social resources to invest in DFS and conservation more generally (Swanson 1993). Without finding ways to benefit economically and socially, farmers are far less likely to take the risks of practicing ecological diversification and agroecology.

\section{FARMER KNOWLEDGE OBSTACLES}

Historically, DFS comprised the dominant agricultural system in the USA and other industrial countries before the 1950s but have largely vanished in much of the USA. The erosion of farmer capacity to practice knowledge-intensive ecological farming is one key factor inhibiting the adoption and scalingup of DFS. In DFS, farmers need to understand physiobiological dimensions not required of monoculture systems dependent on standardized chemical inputs. In managing a diversified farm, they must integrate soil health, climate variability, pest and beneficial insect population dynamics, wildlife movements, water cycles, and other physio-biological components (Roling and Wagemakers 1998). The practice of agroecology relies on developing loops between different farm activities, such as cycling livestock manure into fertilizing crops, and on using ecosystems to generate and regenerate critical farm inputs, including nutrients, pollination, and pest control (Altieri 1992, Gliessman 2007). Diversified farming system farmers need to experiment with many crops and crop varieties to foster agrobiodiversity and resilience to agronomic risks, and to meet consumer demands for quality and variety (Krissoff and Caswell 2002, Gliessman 2007, Kremen and Miles 2012). Furthermore, many diversified farms exist in geographical areas and climates where year-round production is not feasible (except through energy-intensive greenhouses) and seasonal production is insufficient to provision markets.

Yet many farmers today lack access to the extensive knowledge, skills, and practical experience needed to implement DFS effectively. Historically, DFS techniques were transferred to new generations of farmers through social learning in agricultural communities and among farming families. Now, inexperienced farmers often depend on individuals or neighbors to provide guidance, or on information provided through the Internet. In some cases, they may join organic or sustainable agriculture networks, but their existence and resources vary greatly among regions. Many potential farmers may be deterred from adopting DFS practices for lack of the resources, confidence, and social networks that established farmers have (Rodriguez et al. 2009, Raftery 2011). Cultural hesitancy may also be important: some farmers may perceive DFS as an elitist form of agriculture, whereas others see it as a lowly, backward form (M. Bowman and D. Zilberman, unpublished manuscript, for analysis of the advantages of and economic barriers to diversification.).

Conventional extension schemes seldom provide appropriate training and information to farmers to overcome these gaps because they focus on short-term crop productivity and yields to the exclusion of other ecological, economic, and social benefits (McDowell 2001, Warner 2007). In such systems, farmers are rarely treated as collaborative partners who can produce their own credible, scientifically meaningful knowledge. With some enthusiastic individual exceptions, extension advisers are not trained in diversified farming methods or participatory experimentation, leaving many DFS farmers to struggle on their own. Even as DFS practices become more popular, extension advisers are unable to help farmers because their knowledge and techniques have been developed under artificial extension station conditions, not in actual farming situations (Warner 2007). Moreover, this knowledge is mostly developed specifically for conventional agricultural systems, rather than organic or low-input systems (Dawson et al. 2008). For nearly 30 years, numerous reports have called for agricultural extension in the USA to become far more inclusive of farmers and to address sustainable production but with little response, indicating durable resistance (NAS 2010).

Existing farmers also face significant economic risk in switching to DFS (Roling and Wagemakers 2000). They may 
take significant time and resources to learn to become adept in sustainable agriculture or become certified organic producers, are likely to make mistakes, and may jeopardize their livelihoods without a social or economic net in place to withstand the transition. Furthermore, influenced by dominant social and economic views of "efficient" production, farmers may not perceive maintaining environmental stewardship as necessary or beneficial, or may not think in terms of how their land forms part of a larger agro-biodiversity landscape. Their own farming experience may favor adoption of industrialized methods and crops, and indicate that DFS is relatively unproductive and challenging (Bell 2004). As a result, traditional knowledge and cultivars are vanishing across the USA. For example, the Renewing America's Food Traditions network identifies the Appalachian region as perhaps North America's most diverse agricultural region, with 1,400 crop, fruit, and nut varieties historically grown but under threat (Veteto et al. 2011).

Equally important, diversified farming is labor intensive and requires a larger skilled, knowledgeable workforce willing and able to do the work, with associated higher costs, compared with industrialized agriculture. Yet where these skilled farmers and farm workers are to come from is uncertain. Over the past 40 years, farm numbers in the USA have dwindled from 6.5 million farms in 1935 to 2 million in 1997 before rebounding slightly with 200,000 new farms by 2007 (USDANASS 2009). Significant racial and ethnic disparities in the farmer population exist: in 2007, African-Americans ran merely 30,500 of these farms and Latinos operated 82,000 farms, a growth of $14 \%$ from 2002 (USDA-NASS 2010, 2009). The average age of farmers has steadily increased to 57 years, with fewer people taking up farming, as rural youth continue to migrate to urban centers, and both legal and undocumented immigrants, millions working as farm laborers, face steep barriers to entry as farm owners (Shreck et al. 2006, USDA-NASS 2009). Where capital-intensive, large-scale production dominates and fails to support local businesses, employment, and tax revenues, rural areas are experiencing slow population growth or even depopulation (Krannich et al. 2011). Significant disparities in income exist between U.S. rural and urban areas (as of 2009, income levels are $\$ 31,400$ rural to $\$ 41,250$ urban; poverty rates are $16.6 \%$ rural to $13.9 \%$ urban) as well as disparities in educational levels and dependence on federal government support (USDA-NASS 2009).

Combined with increasing poverty and worsening economic conditions, depopulation of rural areas results in lost state/ county revenue and diseconomies of scale for investing in economic and social infrastructure, such as improved roads, processing and packing plants, and farmer markets (Hanson et al. 2008, Krannich et al. 2011). As agri-food companies and retailers have increasingly centralized their processing, distribution, and marketing systems, rural infrastructure has decayed further (Halweil 2002). Thus, small and medium producers must develop alternative processing and transportation projects to compete in non-local markets, increasing their costs even further.

\section{INDUSTRY CONSTRAINTS ON FARMER CAPABILITIES}

Finally, farmers may be restricted in their ability to practice or adopt DFS by supply-chain conditions. In the USA, markets for agricultural products, particularly grains and meat, and increasingly fruits and vegetables as well, are concentrated in a small number of large food-processing, distribution, and retailer firms (e.g., Sysco, U.S. Foodservice, McDonalds, Wal-Mart, and Costco; Hendrickson et al. 2001, Henrickson and Heffernan 2007). Large agri-food firms prefer to source uniform, standardized foods that can be produced year-round with highly predictable quality and yields (Halweil 2002, Hart and Pimentel 2002). They rely on production and marketing contracts with farmers that guarantee prices in exchange for specified product quantities and quality standards. In 2005, $60 \%$ of dairy products, $54 \%$ of vegetables, and $64 \%$ of fruits and nuts were grown under contracts (NAS 2010: 275).

A shift in control from farmer to contractor discriminates against the more variable products (in quality and form) of diversified farms that do not adhere to strict uniform standards. Farmers under contract have little scope to experiment with alternative, agroecological practices. Most recently, scares over $E$. coli breakouts in the USA and Europe have prompted stricter food safety regulations and marketing agreements, resulting in even stricter buyer demands for clean, fecal-free field conditions (Kohnke 2007, Lynch et al. 2009). This has deterred emerging on-farm biodiversity improvements, such as planting of hedgerows, trees, and riparian vegetative strips, that may attract wildlife (Beretti and Stuart 2008).

Increased corporate control over on-farm production conditions, centered on lowest cost and highest yields, also allows large growers to undercut small farmers in seeking market share and price premiums for the growing "sustainable" food market (Freidberg 2004). In selling organic foods, Wal-Mart, for example, has pressured farmers to meet organic certification standards for below-cost prices and to serve its stores, rather than more lucrative marketing avenues such as farmer markets (Gottlieb and Joshi 2010). Large organic farms may meet certification standards without becoming environmentally sustainable or diversified (Kremen et al. 2012). These corporate practices undercut the ability of growers genuinely interested in environmental sustainability and DFS to achieve this vision. Governments are often complicit in this industry exploitation by seeking low costs in institutional food provisioning, notably in buying produce for school lunch programs and food banks. Together, these obstacles reinforce the tendency to see industrialized agriculture as the most efficient mode of production in 
industrial countries, and DFS as relatively less efficient, risky, and difficult to practice.

\section{PUBLIC POLICIES TO PROMOTE DFS}

Diversified farming systems can develop within the U.S. industrialized agriculture system if farmers are collectively willing to change their practices, despite the initial risks of transition, and if they perceive that they can benefit economically. Personal factors such as farmer interest, confidence, and socialization with other farmers are key issues affecting adoption of DFS. If farmers feel that they are part of an agricultural community whose work is valued appropriately, for instance, with regional branding, they are more likely to take the lead in supporting diverse social and ecological landscapes. Policies can create favorable conditions for taking up diversified farming, or remove some institutional and economic obstacles, including through the market. The transition and survival costs of switching to DFS are potentially high, and policies must recognize this reality. In 2010, the NAS reviewed case studies of organic farms from its 1989 report and discovered much instability among these farms, as they went out of business, shrank in size, chose to narrow their crops, or specialize in livestock or crops only (NAS 2010).

The inherently variable, site-specific, and decentralized nature of DFS (see Kremen et al. 2012) poses many tests to conventional policy-making processes and institutions. Diversified farming systems require flexible supports and regulations to manage multiple productive activities on a farm simultaneously and year round. Yet conventional agricultural policy making favors practices that can be readily standardized, reduced to technical specifications, applied in the short term, and diffused in predefined packages across large geographic areas (Pretty 1995). Given the conventional focus on increasing yields and production while rectifying emerging problems with technological fixes, understanding and uptake of a multifunctional landscape approach has been rare. Nevertheless, there are important emerging examples of watershed, habitat, and ecosystem management efforts from which valuable experiences can be learned (e.g., Blomquist and Schlager 2005, Keough and Blahna 2006, Wilgen and Biggs 2011). Local and regional public policies to support DFS already exist in the USA and other industrialized countries, although these may not be supported by national policies because of diverging priorities and political constituencies.

We present four sets of how policies could be strategically aimed to change different aspects of the industrialized agriculture system in the USA while aiding farmers already committed to sustainable practices. We selected these sets from a large range of potential policies that could support DFS (as seen in Table 1), emphasizing policies that fill in the missing knowledge, incentive, and market infrastructure needed to sustain DFS as inherently variable and site-specific systems at landscape scales. (There are many such "infrastructural" policies, such as breeding programs tailored to local DFS, but for reasons of space, we can address only a few.) Targeted to individual growers and farming communities, these "landscape-scale" policies can be leveraged to several ends: to encourage changes in practices and attitudes over time, to draw in more growers, to improve the ability of growers to make enduring changes, and to form grower-buyer-consumer networks that can expand within the deeply entrenched conditions of industrialized agriculture. In some cases, we draw on examples from Australia and the European Union to illustrate these policies.

Table 1. Examples of policies that could nurture DFS

Financial reforms: ensure adequate financial support of DFS through diverse public and private sources; impose carbon taxes on fossil fuel inputs to discourage long-distance transportation and agro-chemicals; impose toxicity taxes on chemical inputs.

Regulatory reforms: make and enforce rules to internalize environmental and social costs while avoiding disproportionate costs for smaller farmers; design food safety regimes that allow diversified farming; harmonize regulations to reduce costs of compliance by diversified farmers.

Planning and land-use changes: use municipal zoning to remove development pressures on peri-urban diversified farms; encourage farming within urban areas; foster landscape-scale planning.

Infrastructure development: build local processing plants and local food aggregation systems and strengthen direct marketing systems to better meet the needs of diversified farming and counter agri-business power over supply chains.

Procurement and nutrition support: preferences for DFS in government purchasing and expansion of nutrition and public health programs to include DFS-sourced foods.

Antitrust enforcement: curb monopolistic and oligopolistic power ("food trusts") in food supply chains; weaken market concentration and retailer control across all food categories.

Campaign finance controls: eliminate unrestricted political donations; prevent agri-business corporations from contributing to political action committees.

Farm Bill reforms: redirect publically financed subsidies for industrialized agriculture to support sustainable agriculture and DFS at the landscape scale.

Sources: Pretty 1995, Buttel 2006, NAS 2010. 
In parallel, other sets of policies can address many of the systemic social conditions reviewed above. In particular, to fully internalize the environmental and social costs of industrialized agriculture not currently borne by agri-food businesses, a combination of "national-scale" taxes on carbon emissions and toxic inputs, restrictions on political campaign financing, enforcement of anti-trust and environmental regulations, protection of worker conditions, and redirection of subsidies to sustainable practices is needed. Requiring nutrition programs to source food from DFS could also help scale up agroecological methods. In turn, "regional-scale" policies are needed to revitalize rural economies through changes in land planning, processing infrastructure, and offfarm employment creation, and thus make pursuing DFS more feasible.

\section{TRANSFORMING AND EXPERIMENTING WITH AGRICULTURAL KNOWLEDGE}

The generation, validation, and transmission of farmer knowledge underlie the adoption of diversified farming practices. Developing DFS requires not only the spread of agro-ecological and experimental capacity among farmers, but also the growth or sustenance of a farming population that is enthusiastic about using management practices that are both knowledge and labor intensive. Researchers suggest that a key motivation for people to become, or remain, farmers is whether their work is cognitively and experientially stimulating and is valued as such (Morgan and Murdoch 2000). In switching to agro-ecological farming, farmers often say that they feel increasingly respected and empowered (Holt-Giménez 2006, Bell 2004). Yet, policy analyses tend to overlook the importance of fostering the ability of growers to carry out their preferred practices and visions for the future. For example, Reganold et al. (2011) defined the key areas for U.S. sustainable agriculture reforms but omitted farmer knowledge and recruitment. Therefore, greater policy support for agroecological practices and DFS has the potential to revitalize a shrinking rural population.

To support the development of farmer knowledge and agency, policy makers can re-prioritize the public agricultural research and extension system from concentrating on industrialized agriculture technologies (Caswell and Day-Rubenstein 2006) to creating the knowledge base and breeding programs needed for diversified, agroecological farming at different scales. The NAS recently concluded that transforming industrialized agricultural systems requires fully integrated research and development (R\&D) and extension efforts to investigate alternative production systems rather than simply seeking to incrementally improve the environmental sustainability of the existing industrial system (NAS 2010). As the NAS noted, "To pursue systemic changes in farming systems, R\&D has to address multiple dimensions of sustainability (productivity, and environmental, economic, and social sustainability) and to explore agro-ecosystem properties" (NAS 2010:528).
Although numerous DFS practices have already been identified and used across the world, relatively little effort has focused on applying agroecological techniques at the often large scale of industrialized farms. The overall cost to government of supporting DFS can be reduced further through greater investment in research and technical services that result in lower input use and costs of production for diversified producers. Thus, governments can help develop new forms of R\&D and extension to mutually exchange information with farmers, agri-food companies, and retailers. Universities across the country can grow a robust cohort of agroecologists over time, helping create a perceptual shift in thinking about agroecology as a set of modern, scientifically verified practices that have much greater credibility with growers, agri-food companies, and governments (Wright 2005).

In this vein, interesting decentralized extension reform efforts have appeared across the USA. For example, in California, a number of small agroecological partnerships between producers, University of California-based researchers, and county extension staff have evolved since the early 1990s, centered on almonds, pears, vegetables, and wine making (Warner 2007, 2008). These partnerships seek to rebuild traditional models of extension around greater participation by producers in designing, testing, and evaluating agroecological practices. University agricultural research projects have slowly focused on projects to improve on-farm practices, with $21 \%$ of publicly funded research now addressing sustainability issues compared with $17 \%$ in 1998 (Caswell and Day-Rubenstein 2006). Seeds and livestock also need to be adapted to diversified farming conditions. Washington State University researchers, for instance, have developed participatory breeding programs in which they collaborate with farmers to develop and test locally relevant, low input varieties (Dawson et al. 2008). Nonetheless, the vast majority of academic and USDA research on landscape-scale sustainable farming and ecosystem functions is focused at the single farm rather than the landscape scale.

Second, policy makers can nurture the growth of peer-to-peer training and farmer experimentation at landscape scales in industrial country settings. As Pretty (1995) points out, the coordinated action of large numbers of environmentally dedicated farmers across the landscape is required because using DFS practices on isolated farms will create ecological services that can be undermined by lack of support from neighboring farmers. Moreover, farmers tend to be most influenced by proof of successful farming methods by their peers or on their own farm (Warner 2007), yet they can take much time to learn from trial and error. Many examples of peer-to-peer training movements have developed worldwide, notably in Latin America where the "campesino-a-campesino" (farmer to farmer) movement has promoted agroecological techniques over the past 35 years (Holt-Giménez 2006). Rather than simply using trial and error, this method allows 
"campesinos" to benefit from the experience of model farmers or "promotores" who teach through participatory workshops and small field experiments. This collaborative grassroots learning was historically important in industrial countries but has become increasingly marginalized (Hassanein 1999, Campbell 1998). Industrialized agriculture has drawn individual farmers into supply chains where they must compete against each other to reduce costs. As a result, industrial countries may have a weakened collective culture that can sustain such learning through dialog (Bell 2004). Nonetheless, a number of efforts to regenerate farmer capabilities and knowledge have emerged in Australia (see Box 1), Europe, and the USA since the 1980s (Bell 2004, Prager and Vanclay 2011).

\section{Box 1:}

The Landcare Scheme in Australia Landcare is a governmentsponsored, community-based program that initially aimed to reverse the effects of land degradation but expanded to include biodiversity and water conservation goals. Beginning in Victoria in 1986, groups have self-organized according to local interest, accelerating after the formation of the National Landcare Program 3 years later. The basic model is a group of 20-30 farmer volunteers meeting every few months at the district level, with the assistance of a trained, government-paid facilitator, to discuss locally relevant issues and define priorities, hold demonstration and training days, and work on management actions such as tree planting, salinity controls, and wildlife corridors (Curtis and de Lacy 1996, Campbell 1998). Starting in 1996, the federal government provided more funding, resulting in 4,500 Landcare groups across the country by the early 2000 s (Prager and Vanclay 2011).

Extensive research suggests that many groups were effective in terms of process in educating farmers about land degradation challenges, the knowledge needed to evaluate their land, and potential management practices to reverse degradation (Curtis and De Lacy 1996, Curtis 1998, 2003). Landholders participating in a group were more likely to build shared understandings of their localized problems, gain information from their peers, and implement specific management practices than landholders not participating (Curtis and De Lacy 1996). Peer pressure and community scrutiny helped create new norms of conservation practices (Minato et al. 2010), with $85 \%$ of participating groups in Western Australia working on biodiversity measures (Simpson and Clifton 2010). However, many Landcare activities did not explicitly address agrobiodiversity protection or ecosystem services, as they were not connected to landscape-scale strategies (Curtis 1998). Landcare also did not foster the development of agroecological knowledge and farm diversification on a large scale. Few measurements of impacts on biodiversity and ecosystem services have been made, although government agencies are now striving to develop procedures to evaluate these outcomes.

Landcare has evolved considerably over the past 25 years. Beginning in 2002, institutional changes meant that funding became more erratic and government agencies sought to control the direction of many groups (Prager 2010). As a result, participation appears to have plateaued, and some groups have vanished, with landholders citing frustration with bureaucratic oversight, contempt for grassroots efforts, and dwindling funds (Prager 2010, Simpson and Clifton 2010). Ongoing rural depopulation and weak interest among younger farmers means that fewer landholders now participate (Simpson and Clifton 2010). Over-dependence on facilitators leads to fatigue and thus steady turnover, destabilizing projects. Nonetheless, Landcareinspired practices have contributed greatly to improved land management and have encouraged a new collaborative spirit in what had been a strongly individualistic farming culture. Significant numbers of farmers (37\% of farming communities at the peak) have participated across the country, leading to the spread of similar schemes in other countries.

The Landcare scheme in Australia illustrates what peer-topeer learning could contribute to DFS in industrial country conditions. Significant reforms to institutional design and participatory decision making at landscape scales, adequate funding mechanisms, and more diverse knowledge systems (particularly agroecological skills) could allow Landcareinspired national networks to create enabling conditions for DFS to thrive. Such movements may engage farmers more effectively than conventional extension programs. Much evidence suggests that farmers are more willing to adopt diversified practices into their established industrialized systems if they can trial the practices on their farms or on shared spaces to avoid excessive risk (Fisk et al. 1998, Somers 1998). If farmers can observe the results, learn from experience more effectively, and be made accountable to their peers in the surrounding landscape for implementing changes, they may be persuaded to switch further to sustainable methods (Bell 2004). Nonetheless, many such learning networks tend to emerge independently of industrial agriculture and governments. Thus, introducing policy mechanisms could undermine their effectiveness, as the Landcare case suggests. It is critical to develop a dynamic balance between policies to encourage the networks and allowing farmers in a particular region to develop their own activities and designs. Equally important, the landscape dimension and agrobiodiversity measurements need to be built into networks from the start to increase their potential impact.

Third, policy makers can support the recruitment and retention of new farmers in sustainable agriculture as a source of "green jobs." The green jobs movement emphasizes environmental technologies but could broaden to include agricultural jobs as well. New entrants, particularly those from non-farm backgrounds and motivated by sustainability ethics, are more likely to use DFS practices and to engage in peer-to-peer sharing (Padel 2001, Prokopy et al. 2008). Despite significant declines in farmer numbers in many industrial countries, there is much new interest in rural and urban farming as a profession, in part due to emerging alternative market opportunities such as community-supported agriculture or farmer markets. In the USA, young, Latino, and women farmers are increasing rapidly in their numbers but still struggle to survive as they 
learn to farm and build their markets (United States Department of Agriculture National Institute of Food and Agriculture (USDA-NIFA) 2006, USDA-NASS 2007). Many immigrant and refugee communities are using traditional farming skills, often agroecological, to produce their own culturally relevant, healthy foods at small scales (Brown 2011, Viva Farms 2011) but lack adequate access to land and credit to become economically sustainable as full-time farmers.

In response, a growing number of non-governmental organizations (NGOs) and teaching farms are emerging across the USA to provide training, technical assistance, and access to land and farming equipment to "beginning farmers and ranchers." For example, the Agriculture and Land-based Training Association (ALBA), located in Salinas, California, provides training in organic horticulture to immigrant farm workers who want to become farmer entrepreneurs (ALBA 2009). Trainees spend 1-2 years trying out their new farming skills on ALBA-owned land and equipment, and sell their produce at the ALBA organic market stand, before launching into competitive farming. Similarly, Viva Farms in Skagit County, Washington, an outgrowth of Washington State University Extension's Small Farms Program, provides incubation facilities and micro-loans to immigrant and young farmers who wish to revive the sustainability of this rich agricultural landscape (Viva Farms 2011). Several regional and national networks now support peer-to-peer learning among young farmers, such as the National Young Farmers' Coalition. In addition, the Grow Food network matches interested people across the USA with farms willing to provide internships, voluntary or paid work, so that they can experience what farming entails.

Such farmer recruitment efforts, however, face significant obstacles because they are voluntary, may not be coordinated, and must work with very limited resources. Unfortunately, new farmers often founder at the point of transition to buying their own farms because of high land prices and lack of credit (Raftery 2011). Although NGOs provide most services at this point, government policies can play a vital role in providing the necessary credit, access to land, learning infrastructure, and direct investments or incentives for new industries to locate in rural regions.

Starting with the 2008 farm bill, the U.S. federal government has provided several nascent supports targeted specifically at beginning farmers and ranchers (Sureshwaran and Ritchie 2011). New farmers can seek direct loans of up to $\$ 300,000$ to buy land. In 2010, the Farm Service Agency lent a total of $\$ 170$ million to 1,225 growers, far more than in the previous 14 years but still far below demand (Beginning Farmers 2011). Since 2009, the Beginning Farmer and Rancher Development Program has given $\$ 35$ million in grants to 69 NGOs and colleges to provide learning opportunities similar to ALBA's pioneering work but likewise cannot meet intensifying demand (Beginning Farmers 2011). Under the individual development account program, the USDA has created several pilot projects across the country to aid beginning farmers to build savings of up to $\$ 10,000$ to buy equipment, with $47 \%$ of recipients from minority groups. A coalition of NGOs is calling for these supports to be expanded greatly into a comprehensive framework in the next farm bill, or the Beginning Farmer and Rancher Opportunity Act of 2011 (Beginning Farmers 2011). In particular, the government could create a portfolio of credit supports for different operational needs, including higher loans to allow for regional differences in land prices, and channel this support through regional and local training centers that also provide training in agroecological and DFS techniques.

More comprehensively, governments can develop policies to revitalize rural economies and provide employment not only for on-farm DFS but a range of supportive economic activities such as renewable energy supply, small- to medium-sized, value-added industries like bio-based chemicals from cellulosic materials and diversified crop and livestock processing and packaging plants, transportation "hubs" for fresh food aggregation, and various service-based industries that market the uniqueness and beauty of the landscape, such as special events planning and agro-tourism.

\section{PROVIDING INCENTIVES FOR AGRICULTURAL RESOURCE CONSERVATION}

In the USA and Europe, there is increasing policy awareness of the need to encourage conservation of natural resources on "working landscapes," rather than simply taking ecologically vulnerable land out of production as was the original intent of Farm Bill conservation programs. The USDA, by far the largest agency allocating conservation funds globally, does not target farm diversification per se, nor efforts to diversify production at the landscape level, but does offer a portfolio of voluntary, incentive-based programs that encourage sustainable environmental management of agricultural land. Altogether, the conservation allocation of the 2008-2012 Farm Bill was approximately $\$ 25$ billion, or an estimated \$5 billion annually, up from \$3 billion during 2003-2007 (Monke and Johnson 2010). This represents about one-half of the funds allocated for commodity programs.

The two major working land conservation programs, Environment Quality Incentives Program (EQIP), started in 1996, and the Conservation Stewardship Program (CStP), formerly the Conservation Security Program, started in 2008, are intended to promote "production and environmental quality as compatible goals" (United States Department of Agriculture Natural Resources Conservation Service (USDANRCS) 2012). EQIP funding increased from $\$ 1.2$ billion in 2008 to an estimated $\$ 1.75$ billion in 2012 , with $5 \%$ set aside for beginning farmers. Funding growth is warranted in the 
2012 Farm Bill, given that USDA estimates that EQIP producer applications exceed funding by three to one, yet current budget constraints make this highly unlikely.

Two financial incentives are offered under EQIP: one shares with producers the costs of installing structural and vegetation improvements, up to a maximum of $75 \%$, and the other makes direct payments for adoption of management practices that result in both on-farm and off-farm environmental benefits, chiefly improved soil and water quality and water and habitat conservation. The majority of producers benefiting from EQIP are defined by the Economic Research Service (ERS) as fulltime "small" and "large" family farmers (sales between $\$ 100,000-250,000$ and $\$ 250,000-500,000$, respectively; Cox 2007:138-139). Sixty percent of EQIP payments are set aside to fund installation of waste management facilities in poultry and livestock operations, mainly to assist ranchers to comply with the Clean Water Act (USDA-NRCS 2012). Although still a small proportion of total acreage supported, beginning in 2008, EQIP began to provide more funding for new farmers (5\%), "socially disadvantaged farmers" (5\%), and \$50 million to assist producers transitioning to organic farming or ranching, or expanding their certified organic operations, up to a total of $\$ 80,000$ per farmer during a 6-year period or a maximum of $\$ 20,000$ per year (NAS 2010:296). Small noncertified organic producers, with less than $\$ 5,000$ in organic sales per year, are also eligible for support under the FY 2012 EQIP Organic Initiative (USDA-NRCS 2012).

The Conservation Stewardship Program encourages producers who have already adopted resource-conserving improvements to continue their land stewardship, and, like EQIP, sets aside 5\% of acreage for new farmers, and another $5 \%$ for disadvantaged farmers. Five-year CStP contracts allow producers to maintain existing conservation practices, or adopt new practices, including eligible crop rotations. Payments are based on costs, income forgone, and expected environmental benefits, not to exceed $\$ 200,000$ per individual over the contract duration. "CStP can be considered an experiment to design a 'green payments' program in which farmers are paid for adoption of conservation practices and not for commodity production" (NAS 2010:297). A partner program, the Conservation Reserve Enhancement Program (CREP), focuses primarily on restoration of degraded river banks by paying farmers to install riparian buffers (NAS 2010). Both CStP and CREP prioritize funding to applicants offering the greatest environmental benefit for the least cost, similarly to the large land retirement Conservation Reserve Program, which pays farmers and ranchers a per-acre rental fee to convert highly eroded farm land to resource-conserving vegetative covers. There is growing scientific evidence that these conservation programs (particularly land retirement) can produce major biodiversity gains (NAS 2010).

As research (Kremen and Miles 2012) shows that DFS are more effective than conventional farming systems in producing ecosystem services, future iterations of USDA conservation programs (particularly CStP) should target diversified producers for support and base more substantial compensation on performance as well as cost sharing. Performance-based payments are more effective at encouraging "management-intensive, knowledge-based conservation systems" that require innovation and risk taking (Cox 2007:133-136). Programs should broaden their geographic focus beyond a relatively small set of regions, expand their criteria from reducing traditional water and land degradation to include ecosystem services and landscape management more explicitly, and simplify administrative requirements for entry (NAS 2010, Government Accountability Office (GAO) $2006 a, b, 2007)$. Government programs can also encourage experimentation and learning by allowing adaptable, not fixed, contracts for conservation (Pretty 2008). Diversified producers may be encouraged to work together across a landscape to produce ecosystem services more effectively if funding is channeled through associations of producers working collaboratively, rather than individual farmers (Cox 2007:131). Most importantly, conservation programs need to be implemented consistently, rather than being subject to repeated temporary suspensions due to budget or administrative problems. Many conservation offices at the county level suffer from severe job insecurity, imperiling the longevity of efforts in the face of intensifying biofuel production (Gillon 2010).

\section{CREATING PAYMENTS FOR ECOSYSTEM SERVICES}

The growth of payments for ecosystem services provided on farms and ranches constitutes another set of emerging, if embryonic, incentives driving sustainable agriculture and land management. Research (Kremen and Miles 2012) shows ample evidence that farmers and ranchers practicing sustainable practices can provide a range of ecosystem services that are vital for both production and environmental quality. In the USA and Latin America, there are nascent private voluntary markets that connect buyers with providers of these services, principally for water quality, wildlife habitat, and carbon sequestration. There are also emerging governmental payments, on behalf of societies, that reward farmers for adopting sustainable practices and that invest in the research and development needed to improve these practices continuously (Farley et al. 2012).

In the USA and Europe, farmers and ranchers who adopt practices that conserve habitat may qualify for biodiversity protection compensation programs. In the USA, biodiversityrelated payments total $\$ 1.5$ to $\$ 2.5$ billion annually, provided through public funds, regulatory offsets, and mitigation banks (Forest Trends 2011). These markets are largely driven by federal and state regulations (such as the Endangered Species Act) aimed at reducing harm to the habitats of threatened or endangered species and wetlands. Private or public developers 
of projects that degrade or destroy habitat and wetlands must offset the losses by ensuring that comparable habitat or wetlands are created elsewhere in the watershed (NAS 2010). Whether or not the "compensatory" habitat or wetlands can match the original sites in terms of ecosystem function is debated intensely among conservation biologists. Since 2004, the "Ecosystem Marketplace's Biodiversity Program" (Forest Trends 2011) has investigated biodiversity markets worldwide to provide information for market participants and "ultimately enable fair, stable, and effective conservation markets to develop" (Forest Trends 2011:iv).

In the USA, such regulatory offset requirements have inspired an industry of environmental mitigation banks that sell credits to developers (buyers) who, in turn, contract with farmers, ranchers and conservation or land trusts (sellers) to create and maintain species habitat or wetlands in perpetuity. As of 2009, over 120 active species banks and nearly 450 wetlands and stream mitigation banks existed in the USA (Forest Trends 2011). Since 2009, these banks have continued to grow in number but at a slower pace due to the recession impeding real estate development. As the economy recovers, farmers may be better able to finance their DFS activities with income from selling biodiversity and wetlands mitigation options on their land.

Similar offset markets are beginning to develop for carbon sequestration and methane capture on "climate smart" farms and ranches that adopt practices to conserve carbon in soil. In the USA, the National Farmers Union and about 12 groups have acted as intermediaries aggregating carbon offsets from producers to sell on the Chicago Climate Exchange to buyers participating in the voluntary carbon market (NAS 2010:290). For example, before closing its program in 2010, the North Dakota Farmers Union helped bring $\$ 7.4$ million to 4,000 participating farmers in return for no-till management practices storing carbon in soil. Unfortunately, the Climate Exchange closed at the end of 2010 because of a weak offset market due to the absence of federal climate laws (McPherson 2010). Moreover, the scientific methods for measuring and monitoring soil carbon emissions and sequestration from different agricultural practices are still developing (Baker et al. 2007, Govaerts et al. 2009). Numerous uncertainties exist regarding whether agriculture can sequester carbon effectively, leading to a weak market for soil carbon offsets. Yet, a large proportion of diversified (and non-diversified) producers, who have already adopted "climate friendly" practices, such as no-tillage and tree planting on degraded land, without carbon credit compensation, could potentially benefit substantially from stronger empirically based carbon markets based on offset rules, such as those in California.

Equally important, governments can transfer resources such as money, risk insurance, storage facilities, knowledge, and food marketing systems to farmer cooperatives, NGOs, local municipalities, and rural communities to enable these actors to implement DFS and agroecology practices that generate and regenerate ecosystem services (Dobbs and Pretty 2004, Farley et al. 2012). In many cases, the market cannot readily provide incentives to growers to produce ecosystem services that are public goods or to engage in DFS activities. As noted above, agroecology and DFS practices are knowledge rich, and are "created in common and used in common" between farmers (Farley et al. 2012:8). These practices are difficult to reduce to patentable knowledge, so private investors have little interest in encouraging them. Conversely, investing in DFS can create benefits for all farmers and societal actors, not merely private investors. Governments, therefore, could make payments for ecosystem services that fund the development of agroecological techniques through university research centers and their distribution through peer-to-peer networks and collaborative extension. Governments could also subsidize credit for farmers to survive in the transition to DFS. These policies were discussed above but can be linked explicitly to provisioning ecosystem services too. They can be adopted now without needing to wait for improved measurements or markets to develop fully.

One nascent example of how this government support could work is the USDA "Farm of the Future" Program, which recently sponsored research on a diverse set of farms and ranches that have successfully augmented traditional production income with market-based payments for ecosystem services either under existing government offset programs or in emerging local trading schemes. Box 2 provides brief descriptions of the five farms and a link to full case studies. The goal of the USDA Program is to stimulate interest in diversified, integrated systems among sellers (farmers, ranchers) and buyers of ecosystem services across the country and to address barriers to participation that have emerged from the research.

Box 2:

Farms of the Future

USDA/EcoAgriculture Partners

(http://www.usda.gov/oce/environmental markets/farm.htm)

Five working landscapes are profiled to illustrate how farmers and ranchers across the USA are participating in environmental markets or receiving payments for ecosystem services.

1. Watson Partners Farm, southern Minnesota receives payments for planting a cover crop with its sugar beets as part of a phosphorus trading program within its cooperative. Cover cropping sequesters phosphorus and offsets discharge from the cooperative's wastewater treatment facility.

2. Buck Island Ranch, Northern Everglades, Florida is one of eight ranches in the Lake Okeechobee watershed 
supplementing its cattle sales with payments for water retention as part of an ecosystem services pilot project.

3. Big River and Salmon Creek Forests, northern California demonstrate a new approach to sustainable forest management that involves a "light touch" harvest plan, the protection of wildlife habitat and water quality, the sale of carbon offsets, and job creation in local rural communities.

4. Sacramento River Ranch, Yolo Co., California sells wetlands and habitat mitigation credits to local developers in addition to its food production on 1,052.2 ha $(2,600$ acres $)$ of cropland and orchards. River Ranch derives more than $50 \%$ of its total profits from mitigation on only $10 \%$ of its farmland.

5. Mudford Farm, Chesapeake Bay, Maryland maintains corn, soybean, and wheat production on its most productive soils while restoring wetlands and wildlife habitat on marginal agricultural land. Returns are generated from a wetland mitigation bank, hunting permits, water quality enhancement, as well as row crops.

These cases illustrate the multiple benefits for farmers diversifying their activities to include conservation and provision of ecosystem services. Farmers can reduce the risk of exposure to falling crop, livestock, or timber prices, increase their overall profit, comply with environmental regulations, and enhance land and water quality. A strong barrier to participation, particularly for small- and medium-sized farmers, is the complicated and costly scientific, legal, and management expertise required to negotiate and implement contracts for ecosystem services, or to access government payments. This barrier can be overcome through cooperation among farmers and partners, such as conservation districts and third-party aggregators, to share expertise and the cost of hiring specialists (Bowman 2010). Another lesson for stimulating this incentive-based innovation is an adequate portfolio of financing, often including "seed" funding from public conservation programs followed by low interest loans. Government, therefore, can play a catalytic role by introducing programs to support ecosystem service provision on diversified farms and ranches (USDA 2010; Farms for the Future, Lessons Learned).

\section{CONNECTING DIVERSIFED FARMERS WITH DIVERSE MARKETS}

Growing consumer demand in industrial countries for healthy, sustainably grown food is influencing the emergence of alternative markets, regional food hub businesses, and community-based food justice alliances in opposition to supply chains and government policies favoring industrialized agriculture (Kremen et al. 2012). These alliances support direct sales markets to enhance consumer awareness about who produces their food and under what conditions, and to leave a greater share of the consumer dollar with producers, making diversified farming more economically viable. The number of U.S. farmers selling directly to individuals and families, most of them limited-resource and small farmers, is steadily growing from an estimated $2 \%$ in the early 1990 s to about $7 \%$, or 60,000 today (NAS 2010:278). In parallel, regional food hubs (or mediating markets) are now emerging throughout the USA to allow small- and mid-sized farmers to better aggregate their products for supply to large-scale buyers such as institutions and retailers (Barham 2012).

Farmers typically combine multiple direct marketing mechanisms to diversify their sales and spread the risk of insufficient buyers. Most direct sales occur through farmer markets and community-supported agriculture (CSA). The appeal to consumers is their increased awareness, through direct contact with farmers, about where, by whom, and how their food is produced. Farmer markets also create new spaces for communities to mobilize around increasing access to sustainably grown and healthy foods. Most importantly, alternative markets can help change societal expectations to accept food prices that fully internalize environmental and social costs. They can help rebuild weakened small-scale distribution and processing infrastructure in the absence of government intervention.

Community-supported agriculture is an attractive market for small- and mid-sized diversified farmers seeking flexible buyers for their seasonal produce. In a CSA scheme, consumers sign up with an individual farm to have boxes filled with whatever crops or products are harvested that week (primarily vegetables and fruits, but also eggs, herbs, flowers, and occasionally meat) delivered to them via designated distribution points. Community-supported agriculture developed in Europe and Japan and has spread to North America and elsewhere globally, taking on different arrangements and goals depending on local and cultural contexts (Galt et al. 2012). In 2009, a Local Harvest survey showed 2,877 farms were participating in CSA throughout the 50 states (NAS 2010:279-280), and a more recent study estimates 3,637 CSA farms nationwide (Galt et al. 2012). Estimating an average of 50 members per CSA, that calculates to over 180,000 households, or about one million people sourcing fresh food from CSAs by 2012.

Farmer markets across the USA are growing at an even faster rate than CSAs (about 5\% annually since the late 1990s) because they offer benefits not associated with CSAs, namely, direct contact with farmers, individual choice regarding quantity, quality, and price of purchases, and socializing at neighborhood markets (Smithers et al. 2008). Farmer markets 
feature fresh produce grown locally, usually within a 2-h drive radius, but vary in the extent to which they provide organic produce or foods produced using fair labor practices. Many consumers develop loyalty for particular farms that adhere to the values and attributes most important to them, including taste, variety, pesticide free, organic, socially responsible/fair food as well as price and affordability. The number of farmer markets nationally now exceeds 7,500 (USDA 2011). By 2015 , government estimates predict a range of between 65,000 and 180,000 farmers participating in farmer markets nationwide (up to $40 \%$ of all smaller farmers), generating approximately $\$ 1.5$ billion in revenue (NAS 2010:279). Still, this represents a tiny fraction of total food sales in the USA (about $0.03 \%$ ), emphasizing the importance of also changing industrialized agriculture supply chains through mediating markets or aggregation hubs.

Although CSAs and farmer markets provide an attractive incentive for farmers to grow diverse products to meet demand and generally offer higher prices than non-direct sales, they face important constraints in their expansion. One is competition from supermarket chains, which increasingly feature local and organic food that is primarily grown by industrialized, large-scale producers. The success of this competition reflects a lack of capacity of small- and mid-sized producers to meet the requirements of large-scale buyers regarding volume, quality, packaging, and food safety, while meeting the bottom line of the lower production costs of industrialized agriculture (Fridmann 2007). Large hotels and restaurants are likewise reluctant to source local foods from a large number of small farmers because of high transaction costs and variable quality. Between 1992 and 2007, the number of mid-sized farms (with sales ranging from $\$ 50,000$ to $\$ 500,000)$ declined by $21 \%$, due in part to their increasing inability to compete effectively in industrialized supply chains, such as Walmart (Barham 2012, Diamond and Barham 2012). These farms are too large to rely on farmer markets and CSAs as their sole outlets, and thus require mediating markets (or regional and local hubs that manage aggregation and distribution of food) to reduce transaction costs and thus be competitive. One example is the Aggregation and Marketing Center of northern California in cooperation with the California Alliance with Family Farmers. Another is the Local Food Hub in Charlotteville, Virginia, which encourages the adoption of DFS and offers apprenticeships to new farmers. Such hubs are still a new part of the food system, with $60 \%$ of the 162 hubs existing by 2011 being in operation for less than 5 years (Diamond and Barham 2012). Many mid-sized farmers, who still control the majority of U.S. agricultural land, would stay in business and might adopt diversified farming practices if they have adequate market support (Lyson et al. 2008). Small farmers can also join these mediating markets to strengthen their position further.
Another constraint is the persistent mainstream culture, particularly in the USA, that is accustomed to year-round access to cheap produce shipped from across the country and the world. The "Buy Fresh, Buy Local" education and marketing campaign is finding some success in delivering an alternative message to consumers and food-related businesses. "Buy Fresh, Buy Local" shares a common brand and vision nationally but operates through different chapters at the state level. For instance, in California, the Community Alliance for Family Farmers supports the campaign with ready access to information on where local foods may be purchased within $8.05 \mathrm{~km}$ (5 miles) of any zip code in the state. However, affordability of produce through direct markets is a real issue for low-income families. Some CSAs and urban gardens are addressing this concern with discounted or free bags of fresh produce for food-insecure populations. Market saturation is another emerging problem in some towns and neighborhoods with multiple farmer markets and CSAs, driving prices down to levels no longer profitable for many farmers (Zezima 2011). These problems can be overcome with better growth planning and infrastructure support from local governments and nonprofit organizations that support farmer markets, as well as better coordination among farmers to reduce transportation costs. The USDA also provides a small amount of support ( $\$ 10$ million in 2011) to expand access to farmer markets, especially in under-served neighborhoods.

Another major opportunity for diversified growers is marketing to public and private institutions serving food to students (schools, universities), patients (hospitals, nursing homes), employees (government agencies, companies), health care members (medical insurers), and inmates (prisons) (Izumi et al. 2010, Pearson et al. 2011). This is a vast, largely untapped market that could be worth billions, given an enabling set of policies to expand both supply and demand for local foods. Growing numbers of hotels and restaurants are also featuring fresh, sustainably grown foods sourced from local producers. Government procurement policies are particularly important in expanding institutional markets. For example, schools must comply with new national, state, and local nutritional guidelines and regulations for their breakfast and lunch menus (Nugent 2011). Policies (e.g., the 2009 U.S. stimulus package) enabling schools to purchase and prepare fresh foods for children, rather than processed foods, and finance the kitchens and equipment needed to serve fresh meals to students will enhance their health and create a major market opportunity for local diversified farmers. Additionally, procurement rules that allow government agencies to pay a premium for local products will expand supply by local farms and thus their profitability. Similarly, hospital systems could redesign their "Wellness Programs" to include improved access to fresh foods grown locally and sustainably. Farmer markets are appearing in hospital car parks (such as Kaiser Oakland in California). Already, hundreds of hospitals are working to 
change food procurement for cafeterias and patient trays (Health Care Without Harm 2011). Public health research suggests that increasing consumption of fresh fruits and vegetables can lead to reduced morbidity and mortality (Thomas Nelson, President, Capay Valley Farm Shop, Esparto, California personal communication 2010).

One important lesson from these collective experiments with creating diverse markets is that mediating markets and direct marketing both need multiple product differentiation approaches, including local identity, group branding, and sustainable production. Particularly interesting is the development of market branding that emphasizes a particular region and its diversified landscape, pooling the resources of multiple producers within that landscape. Regional branding helps raise awareness among consumers that anything grown in that region has desirable qualities, such as taste, freshness, agrobiodiversity, and cultural richness. Europe is the leader in this "place of origin" branding, with government recognition, regulation, and marketing support, and has been for centuries. Such efforts remain nascent in the USA; one case is the Capay Valley in California (see Box 3: Minkoff and Marsh 2009).

\section{Box 3:}

\section{Marketing Diverse Produce from the Capay Valley}

In the Capay Valley, local farmers, ranchers, and community organizers have worked over 30 years to maintain the rural landscape and encourage ecologically based agriculture. Farmers in the valley are concerned about the growing disconnect between rural and urban people and the need to educate city residents about where their food comes from.

As the popularity of sustainable and locally grown products has increased, so has the number of farms growing fruits, vegetables, and nuts organically. Thaddeus Barsotti of Capay Organics (the largest organic producer in the Valley) argues that organic standards have been degraded now that nearly every major agriculture company has an organic brand. Corporate organic production of fruits and vegetables is primarily large-scale monoculture with little attention given to ecological or social sustainability. Barsotti also contends that a major bottleneck for improving producer-consumer relations is in the mainstream supply chain and distribution of produce, which limits consumers' direct access to farmers. He proposes widely expanding Community Supported Agriculture (CSA) programs as an alternative to mainstream distribution. The main challenge for the Capay Valley to thrive as a diverse agricultural landscape is the ability of farmers and ranchers to find a mix of year-round markets for its products. The Valley's three local towns need to maintain year-round employment for their families and school attendance for their children. Capay Valley Vision (CVV) was formed to help the residents of the Valley collaborate to create a plan for regional development.

As an outcome, CVV has created the Capay Valley Grown regional brand. There are no formal requirements or guidelines for a grower to use the label except to be located in the Valley and practice sustainable land stewardship. The brand represents common values for participating growers and a label recognized by consumers as a symbol of sustainable farming. It especially benefits small and lesserknown farmers who could not afford their own branding. The Capay Valley Farm Shop is a collaborative of over a dozen family farms that sell "Farm Shares" in their multi-farm CSA. The Farm Shop profiles their members, community partners, seasonal produce, recipes, CSA choices, and subscriptions over the Internet. Farm Shop president Thomas Nelson strongly advocates expanding access to local, seasonal food in low-income neighborhoods and as part of health care. $\mathrm{He}$ is leading discussions with a major health care provider, Kaiser Permanente, to use Capay Valley Grown foods in its hospitals and wellness programs.

In terms of policies, governments can invest in building the aggregation, storage, packaging, and transportation infrastructure needed, develop regional land-use plans that encourage small- and mid-sized producers to integrate together into hubs, and provide rules, institutional forms, and credit for mediating markets. Governments can also help provide capital for business management systems to coordinate supply chains and for technical aid to expand grower capacity to meet buyer requirements. Following the European example, they can create rules for regional branding.

Educational innovation is central to the success of newly diversified markets. Both direct and mediating market approaches would be more influential in scaling up DFS if the ecosystem services and ecological diversification that they can embody were better understood and valued by consumers and institutions alike. For instance, consumers increasingly understand the soil and water quality benefits of organic agriculture, but do not appreciate the added ecological and social values of growing organically in diverse production systems vs. monocultures. They are less able to identify what specific DFS practices may be. As a result, CSAs, farmer markets, and institutional purchasers may not source foods preferentially from diversified producers. Thus, corporate organic producers can seize an increasing share of consumer demand for organic foods, unless environmental and social sustainability is built into buying requirements. Conversely, educated institutional buyers and governments could use their purchasing power to help diversify farming landscapes and ensure fair worker treatment. Public policies to improve consumer knowledge about DFS through mass media, school programs to expose children to diversified farms and foods, new generations of eco-labels and certification, and technologies to trace foods back to their sources could strengthen the ability of consumers to choose DFS-sourced foods.

Finally, since 2008, the proportion of U.S. families with children experiencing hunger and food insecurity has grown markedly to $25 \%$, due to economic recession and rising 
unemployment. In 2012, nearly 50 million people (or one in seven Americans) are receiving "food stamps" funded by the Supplemental Nutrition Assistance Program or SNAP (Food Research and Action Center 2012). Food support is by far the greatest category of federal agricultural spending, and should not be overlooked by advocates of DFS. More than $70 \%$ of appropriations for the 2012 Farm Bill will fund mandated SNAP payments for the growing number of eligible families and individuals. These payments could also be designed to increase the proportion of food sourced from DFS, thus improving both food security and environmental sustainability. Already, the Fair Food Network has developed the Double Up Food Bucks program, which works with farmer markets to double the value of SNAP dollars spent at these outlets (Fair Food Network 2012). Public debates over the 2012 Farm Bill allow DFS advocates to ally with campaigners for the hungry and their access to healthy food, thus creating a more robust pressure on Congress to reform agricultural policies.

\section{CONCLUSIONS}

Developing supportive public policies is central to the scalingup and survival of diversified farming systems. Diversified farming systems depend on the willingness and capacity of farmers to diversify their farms, but they need support and incentives to help survive the risks of changing from conventional to alternative production practices and to work together more collaboratively at the landscape level. Diversified farming systems face multiple obstacles that include the existing political economy of industrialized agriculture, access to affordable land and credit, the erosion of farmer knowledge, and biases in agricultural extension toward industrialized methods, the weakening of rural economies, and corporate concentration in supply chains. No single policy can hope to address all of these challenges; both top-down and bottom-up policies at landscape, regional, and national scales are needed to create systemic changes and the enabling conditions for these changes.

We have considered four sets of policies to nurture greater ecological diversification at the landscape scale: reformed research and extension systems together with expanded farmer recruitment and peer-to-peer learning; greater investment in agricultural conservation programs; further development and support for ecosystem services on farms and at the landscape scale; and expansion and reform of direct and mediated markets. Together, these policies could help give established and new growers the resources they need to develop and use DFS practices, namely knowledge, techniques, and technologies adapted to landscape conditions; access to land and credit while making a transition to or entering diversified farming; financial incentives, cost sharing, and income to pay for new practices; and new or expanded markets for their ecologically sustainable products. To fully achieve an ecologically based, sustainable agriculture will require the accompanying growth of new and politically strong alliances of farmers, rural communities, environmentalists, consumers, and taxpayers. Without raised awareness and direct political involvement through these alliances, policy makers are far less likely to seek systemic change.

Responses to this article can be read online at: http://www.ecologyandsociety.org/issues/responses. $\mathrm{php} / 5041$

\section{Acknowledgments:}

We thank Maywa Montenegro, Claire Kremen, Christopher Bacon, Annie Shattuck, Ryan Galt, Kendra Klein, and the members of the Diversified Farming Systems Roundtable for their valuable feedback.

\section{LITERATURE CITED}

Agriculture and Land-Based Training Association (ALBA). 2009. Welcome. [online] URL: http://www.albafarmers.org/ index.html.

Alston, J., J. Beddow, and P. Pardey. 2009. Agricultural research, productivity, and food prices in the long run. Science 325(5945):1209-1210. http://dx.doi.org/10.1126/science.1170451

Altieri, M. A. 1992. Agroecological foundations of alternative agriculture in California. Agriculture, Ecosystems and Environment 39:23-53. http://dx.doi.org/10.1016/0167-8809 (92)90203-N

Baker, J., T. Ochsner, R. Venterea, and T. Griffis. 2007. Tillage and soil carbon sequestration-What do we really know? Agriculture, Ecosystems \& Environment 118( 1-4):1-5. http:// dx.doi.org/10.1016/j.agee.2006.05.014

Barham, J. 2012. Regional food hubs: one solution for overcoming barriers to local production. Agricultural Marketing Service, U.S. Department of Agriculture, Washington, D.C., USA. [online] URL: http://www.ams.usda. govl

Beginning Farmers. 2011. Beginning farmer and rancher flyin. Beginning Farmers, Michigan State University, East Lansing, Michigan, USA. [online] URL: http://www. beginningfarmers.org/beginning-farmer-and-rancher-opportunityact-of-2011/

Bell, M. M. 2004. Farming for us all: practical agriculture and the cultivation of sustainability. Pennsylvania State University Press, University Park, Pennsylvania, USA.

Beretti, M., and D. Stuart. 2008. Food safety and environmental quality impose conflicting demands on Central 
Coast growers. California Agriculture 62(2):68-73. http://dx. doi.org/10.3733/ca.v062n02p68

Blomquist, W., and E. Schlager. 2005. Political pitfalls of integrated watershed management. Society and Natural Resources 18(2):101-117. http://dx.doi.org/10.1080/089419$\underline{20590894435}$

Bowman, M. 2010. Farm of the future. Working lands for ecosystem services. Center for Sustainable Resource Development, University of California, Berkeley, California, Ecoagriculture Partners, Washington, D.C., USA, and U.S. Department of Agriculture, Washington, D.C., USA. http:// dx.doi.org/10.2307/1349531

Brown, P. L. 2011. When the Uprooted Put Down Roots. New York Times, 9 October 2011.

Buck, L., and S. Scherr. 2011. Moving ecoagriculture into the mainstream. Pages 15-25 in Worldwatch Institute. State of the World 2011. Worldwatch Institute, Washington, D.C., USA.

Buttel, F. 2006. Sustaining the unsustainable: agro-food systems and environment in the modern world. Pages 213229 in P. J. Cloke, T. Marsden, and P. H. Mooney, editors. Handbook of rural studies. Sage Publications, Thousand Oaks, California, USA. http://dx.doi.org/10.4135/9781848608016. $\underline{\mathrm{n} 15}$

Campbell, A. 1998. Fomenting synergy: experiences with facilitating Landcare in Australia. Pages 232-247 in N. R. Roling and M. A. E. Wagemakers, editors. Facilitating sustainable agriculture: participatory learning and adaptive management in times of environmental uncertainty. Cambridge University Press, Cambridge, UK.

Canning, P. 2011. A revised and expanded food dollar series: a better understanding of our food costs. Economic Research Report Number 114. U.S. Department of Agriculture, Economic Research Service, Washington, D.C., USA. [online] URL: www.ers.usda.gov/Publications/ERR114/ ERR114.pdf

Carpenter, S. 2008. Phosphorus control is critical to mitigating eutrophication. Proceedings of the National Academy of Sciences 105(32):11039-11040. http://dx.doi.org/10.1073/ pnas.0806112105

Caswell, M., and K. Day-Rubenstein. 2006. Agricultural research and development. U.S. Department of Agriculture, Economic Research Service, Washington, D.C., USA.

Clapp, J., and D. Fuchs, editors. 2009. Corporate power in global agrifood governance. MIT Press, Cambridge, Massachusetts, USA.

Cox, C. 2007. U.S. agriculture conservation policy and programs: history, trends and implications. Pages 113-146 in K. Arha, T. Josling, D. A. Sumner, and B. H. Thompson, editors. U.S. agricultural policy and the 2007 farm bill. Woods
Institute for the Environment, Stanford, California, USA. http://dx.doi.org/10.4018/978-1-59904-865-9.ch028

Curtis, A. 1998. Agency-community partnership in Landcare: lessons for state-sponsored citizen resource management. Environmental Management 22(4):563-574. http://dx.doi. org/10.1007/s002679900128

Curtis, A. 2003. Reflecting on the Landcare experience. A report based on information held within ABARE and BRS. ABARE, Canberra, Australia.

Curtis, A., and T. De Lacy. 1996. Landcare in Australia: does it make a difference? Journal of Environmental Management 46:119-137.

Dawson, J. C., K. Murphy, and S. S. Jones. 2008. Decentralized selection and participatory approaches in plant breeding for low-input systems. Euphytica: The International Journal of Plant Breeding 160:143-154. http://dx.doi. org/10.1007/s10681-007-9533-0

Diamond, A., and J. Barham. 2012. Money and mission: moving food with value and values. Journal of Agriculture, Food Systems, and Community Development. doi:10.5304/ jafscd.2011.014.013. http://dx.doi.org/10.5304/jafscd.2011.014.013.

Dobbs, T., and J. N. Pretty. 2004. Agri-environmental stewardship schemes and "multifunctionality." Review of Agricultural Economics 26(2):220-237. http://dx.doi. org/10.1111/j.1467-9353.2004.00172.x

Environmental Working Group (EWG). 2011. EWG farm subsidy database. Environmental Working Group, Washington, D.C., USA. [online] URL: http://farm.ewg.org/farm/ regionsummary.php?fips $=00000$

Faeth, P., and J. Westra. 1993. Alternatives to corn and soybean production in two regions of the United States. Pages 63-92 in P. Faeth, editor. Agricultural policy and sustainability: case studies from India, Chile, the Philippines, and the United States. World Resources Institute, Washington, D.C., USA.

Fair Food Network. 2012. Double Up Food Bucks program. Fair Food Network, Ann Arbor, Michigan, USA. [online] URL: http://www.doubleupfoodbucks.org/

Farley, J., A. Schmitt, J. Alvez, and N. Ribeiro de Freitas, Jr. 2012. How valuing nature can transform agriculture. Solutions 2(6):64-73.

Fisk, J., O. Hesterman, and T. Thorburn. 1998. Integrated farming systems: a sustainable agriculture learning community in the USA. Pages $217-235$ in N. R. Roling and M. A. E. Wagemakers, editors. Facilitating sustainable agriculture: participatory learning and adaptive management in times of environmental uncertainty. Cambridge University Press, Cambridge, UK. 
Food Research and Action Center. 2012. SNAP participation inched up slightly in July 2012. Food Research and Action Center, Washington, D.C., USA. [online] URL: http://frac. org/reports-and-resources/snapfood-stamp-monthly-participationdatal

Forest Trends. 2011. State of biodiversity markets. Global Environmental Facility Secretariat, Washington, D.C., USA. [online] URL: http://www.thegef.org/gef/node/4665

Freidberg, S. 2004. The ethical complex of corporate food power. Environment and Planning D 22,:513-531. http://dx. doi.org/10.1068/d384

Friedmann, H. 2007. Scaling up: bringing public institutions and food service corporations into the project for a local, sustainable food system in Ontario. Agriculture and Human Values 24(3):389-398. http://dx.doi.org/10.1007/s10460-006-9040-2

Friedmann, H., and P. McMichael. 1989. Agriculture and the state system: the rise and decline of national agricultures, 1870 to the present. Sociologia Ruralis 29(2):93-117. http://dx.doi. org/10.1111/j.1467-9523.1989.tb00360.x

Galt, R., L. O'Sullivan, J. Beckett, and C. Hiner. 2012. Community supported agriculture is thriving in the Central Valley. California Agriculture 66(1):8-14.

Gillon, S. 2010. Fields of dreams: negotiating an ethanol agenda in the Midwest United States. Journal of Peasant Studies 37(4):723-748 . http://dx.doi.org/10.1080/03066150.2010 .512456

Glebe, T. 2007. How legitimate are agri-environmental payments? Review of Agricultural Economics 29(1):87-102.

Gliessman, S. R. 2007. Agroecology: the ecology of sustainable food systems. CRC Press, Boca Raton, Florida, USA.

Gottlieb, R., and A. Joshi. 2010. Food justice. MIT Press, Cambridge, Massachussetts, USA.

Govaerts, B, N. Verhulsta, A. Castellanos-Navarrete, K. D. Sayre, J. Dixon, and L. Dendooven. 2009. Conservation agriculture and soil carbon sequestration: between myth and farmer reality. Critical Reviews in Plant Sciences 28(3):98117. http://dx.doi.org/10.1080/07352680902776358

Government Accountability Office (GAO). $2006 a$. Conservation security program: despite cost controls, improved USDA management is needed to ensure proper payments and reduce duplication with other programs. GAO-06-312, GAO, Washington, D.C., USA.

Government Accountability Office (GAO). 2006b. Improved management controls can enhance effectiveness of key conservation programs. GAO-09-528T, GAO, Washington, D.C., USA.
Government Accountability Office (GAO). 2007. USDA should improve its management of key conservation programs to ensure payments promote environmental goals. GAO-07-370T, GAO, Washington, D.C., USA.

Halweil, B. 2002. Home grown: the case for local food in a global market. Paper \#163, Worldwatch Institute, Washington, D.C., USA.

Haniotis, T. 2007. The 2003 reform of the European Union's common agricultural policy and its relevance to the U.S. farm policy debate. Pages 53-74 in K. Arha, T. Josling, D. A. Sumner, and B. H. Thompson, editors. U.S. agricultural policy and the 2007 farm bill. Woods Institute for the Environment, Stanford, California, USA.

Hanson J. D, J. Hendrickson, and D. Archer. 2008. Challenges for maintaining sustainable agricultural systems in the United States. Renewable Agriculture and Food Systems 23:25-334.

Hart, K. A., and D. Pimentel. 2002. Cosmetic standards (blemished food products and insects in food). Pages 152-154 in D. Pimental, editor. Encyclopedia of pest management. Marcel Dekker, New York, New York, USA. http://dx.doi. org/10.1201/NOE0824706326.ch58

Hassanein, N. 1999. Changing the way America farms: knowledge and community in the sustainable agriculture movement. University of Nebraska Press, Lincoln, Nebraska, USA.

Health Care Without Harm. 2011. Menu of change: healthy food in health care. A 2011 program report with highlights, awards and survey results. [online] ULR: http://www. healthyfoodinhealthcare.org/issues.awards.php

Hendrickson, M., and W. Heffernan. 2007. Concentration of agricultural markets. Department of Rural Sociology, University of Missouri, Columbia, Missouri, USA. [online] URL: http://www.foodcircles.missouri.edu/07contable.pdf

Hendrickson, M., W. Heffernan, P. Howard, and J. Heffernan. 2001. Consolidation in food retailing and dairy: implications for farmers and consumers in a global food system. National Farmers Union, Washington, D.C., USA. [online] URL: http://www.foodcircles.missouri.edu/whstudy2.pdf

Holt-Giménez, E. 2006. Campesino-a-campesino: voices from Latin America's farmer to farmer movement for sustainable agriculture. Food First Books, Oakland, California, USA.

Izumi, B., W. Wright, and M. W. Hamm. 2010. Farm to school programs: exploring the role of regionally-based food distributors in alternative agrifood networks. Agriculture and Human Values 27(3):335-350. http://dx.doi.org/10.1007/ s10460-009-9221-X 
Keough, H., and D. Blahna. 2006. Achieving integrative, collaborative ecosystem management. Conservation Biology 20(5):1373-1382. http://dx.doi.org/10.1111/j.1523-1739.2006.00445. $\underline{\mathrm{x}}$

Kohnke, M. 2007. Reeling in a rogue industry: lethal E. coli in California's leafy green produce and the regulatory response. Drake Journal of Agricultural Law 12:493.

Krannich, R., A. E. Luloff, and D. R. Field. 2011. Putting rural community change in perspective. Pages 109-121 in R. Krannich, A. E. Luloff, and D. R. Field. People, places and landscapes social change in high amenity rural areas series: landscape series, Vol. 14. Springer Publishers, New York, New York, USA. http://dx.doi.org/10.1007/978-94-007-1263-8 2

Kremen, C., A. Iles, and C. Bacon. 2012. Diversified farming systems: an agroecological, systems-based alternative to modern industrial agriculture. Ecology and Society 17(4): 44. http://dx.doi.org/10.5751/ES-05103-170444

Kremen, C., and A. Miles. 2012. Ecosystem services in biologically diversified versus conventional farming systems: benefits, externalities, and trade-offs Ecology and Society 17 (4): 40. http://dx.doi.org/10.5751/ES-05035-170440

Krissoff, B., and J. Caswell. 2002. Global food trade and consumer demand for quality. Kluwer Academic, New York, New York, USA.

Levins, R. A. 2000. Willard Cochrane and the Americanfamily farm. University of Nebraska Press, Lincoln, Nebraska, USA.

Lynch, M. F., R. V. Tauxe, and C. W. Hedberg. 2009. The growing burden of foodborne outbreaks due to contaminated fresh produce: risks and opportunities. Epidemiology and Infection 137:307-315. http://dx.doi.org/10.1017/

$\underline{\text { S0950268808001969 }}$

Lyson, T. A. 2004. Civic agriculture: reconnecting farm, food, and community. Tufts University Press, Medford, Massachusetts, USA.

Lyson, T., G. W. Stevenson, and R. Welsh. 2008. Food and the mid-level farm: renewing an agriculture of the middle. MIT Press, Cambridge, Massachusetts, USA.

McDowell, G. R. 2001. Land grant universities and extension into the 21 st century. Iowa State University Press, Ames, Iowa, USA.

McPherson, J. 2010. Carbon credit programs for farmers fail without climate bill. Huffington Post. [online] URL: http:// www.huffingtonpost.com/2010/12/06/carbon-credit-programsfo_n_792424.html

Minato, W., A. Curtis, and C. Allan. 2010. Social norms and natural resource management in a changing rural community. Journal of Environmental Policy and Planning 12(4):381403. http://dx.doi.org/10.1080/1523908X.2010.531084
Minkoff, L., and R. Marsh. 2009. Marketing local food of the Capay Valley. Agriculture Bridge Case Study/USDA/ EcoAgriculture Partners. [online] URL: http://www. agriculturebridge.org/

Monke, J., and Johnson, R.. 2010. Actual farm bill spending and cost estimates. Congressional Research Service, Washington, D.C., USA. [online] URL: http://adriansmith. house.gov/sites/adriansmith.house.gov/files/CRS\%20-\%20Farm\% 20Bill\%20Spending.pdf

Morgan, K., and J. Murdoch. 2000. Organic vs. conventional agriculture: knowledge, power and innovation in the food chain. Geoforum 31:159-173. http://dx.doi.org/10.1016/ S0016-7185(99)00029-9

National Academy of Sciences (NAS). 2010. Drivers and constraints affecting the transition to sustainable farming practices. Pages 271-350 in Committee on Twenty-First Century Systems Agriculture. Toward sustainable agricultural systems in the $21^{\text {st }}$ century. NAS Press, Washington, D.C., USA.

Nugent, R. 2011. Bringing agriculture to the table: how agriculture and food can play a role in preventing chronic disease. Chicago Council on Global Affairs. Chicago, Illinois, USA.

Padel, S. 2001. Conversion to organic farming: a typical example of the diffusion of an innovation. Sociologia Ruralis 41(1):40-61. http://dx.doi.org/10.1111/1467-9523.00169

Pearson, D., J. Henryks, and H. Jones. 2011. Organic food: what we know (and do not know) about consumers. Renewable Agriculture and Food Systems 26:171-177. http://dx.doi. org/10.1017/S1742170510000499

Pollan, M. 2006. The omnivore's dilemma: a natural history of four meals. Penguin Books, New York, New York, USA.

Prager, K. 2010. Local and regional partnerships in natural resource management: the challenge of bridging institutional levels. Environmental Management 46:711-724. http://dx. doi.org/10.1007/s00267-010-9560-9

Prager, K., and F. Vanclay. 2010. Landcare in Australia and Germany: comparing structures and policies for community engagement in natural resource management. Ecological Management and Restoration 11(3):187-193. http://dx.doi. org/10.1111/j.1442-8903.2010.00548.x

Pretty, J. 1995. Regenerating agriculture: policies and practice for sustainability and self-reliance. Island Press, Washington, D.C., USA.

Pretty, J. 2008. Agricultural sustainability: concepts, principles and evidence. Philosophical Transactions of the Royal Society B 363:447-465. http://dx.doi.org/10.1098/ rstb.2007.2163 
Prokopy, L. S., K. Floress, D. Klotthor-Weinkauf, and A. Baumgart-Getz. 2008. Determinants of agricultural best management practice adoption: evidence from the literature. Journal of Soil and Water Conservation 63(5):300-311.

Raftery, I. 2011. Young farmers find huge obstacles to getting started. New York Times 13 November 13: A24.

Reganold J.P., D. Jackson-Smith, S. S. Batie, R. R. Harwood, J. L. Kornegay, D. Bucks, C. B. Flora, J. C. Hanson, W. A. Jury, D. Meyer, A. Schumacher, H. Sehmsdorf, C. Shennan, L. A. Thrupp, and P. Willis. 2011. Agriculture. Transforming U.S. agriculture. Science 332:670-671. http://dx.doi. org/10.1126/science. 1202462

Rodriguez, J. M., J. J. Molnar, R. A. Fazio, E. Snydor, and M. J. Lowe. 2009. Barriers to adoption of sustainable agricultural practices: change agent perspectives. Renewable Agriculture and Food Systems 24(1):60-71. http://dx.doi.org/10.1017/ $\underline{\mathrm{S} 1742170508002421}$

Roling, N. R., and M. A. E. Wagemakers, editors. 1998. Facilitating sustainable agriculture: participatory learning and adaptive management in times of environmental uncertainty. Cambridge University Press, Cambridge, UK.

Shreck, A., C. Getz, and G. Feenstra. 2006. Social sustainability, farm labor, and organic agriculture: findings from an exploratory analysis. Agriculture and Human Values 23(4):239-249. http://dx.doi.org/10.1007/s10460-006-9016-2

Simpson, G., and J. Clifton. 2010. Funding and facilitation: implications of changing government policy for the future of voluntary Landcare groups in Western Australia. Australian Geographer 41(3):403-423. http://dx.doi.org/10.1080/0004$\underline{9182.2010 .498043}$

Smithers, J., J. Lamarche, and A. E. Joseph. 2008. Unpacking the terms of engagement with local food at the farmers' market: insights from Ontario. Journal of Rural Studies 24 (3):337-350. http://dx.doi.org/10.1016/j.jrurstud.2007.12.009

Somers, N. 1998. Learning about sustainable agriculture: the case of Dutch arable farmers. Pages 125-133 in N. R. Roling and M. A. E. Wagemakers, editors. Facilitating sustainable agriculture: participatory learning and adaptive management in times of environmental uncertainty. Cambridge University Press, Cambridge, UK.

Sumner, D., K. Arha, and T. Josling. 2007. Commodity policy and the 2007 farm bill. Pages ??? in K. Arha, T. Josling, D. A. Sumner, and B. H. Thompson, editors. U.S. agricultural policy and the 2007 farm bill. Woods Institute for the Environment, Stanford, California, USA.

Sureshwaran, S., and S. Ritchie, 2011. U.S. farm bill resources and programs for beginning farmers. Choices: The Magazine of Food, Farm and Resource Issues 26(2). [online] URL: http://www.choicesmagazine.org/choices-magazine/theme-articles/ innovations-to-support-beginning-farmers-and-ranchers/us-farmbill-resources-and-programs-for-beginning-farmers- http:// dx.doi.org/10.2753/RSS1061-1428130138

Swanson, L. 1993. Agro-environmentalism: the political economy of soil erosion in the USA. Pages 99-118 in S. Harper, editor. The greening of rural policy. Bellhaven, London, UK.

United States Department of Agriculture (USDA). 2010. Farm of the future project. USDA, Washington, D.C., USA. [online] URL: http://www.usda.gov/oce/environmental markets/farm. htm\#cases

United States Department of Agriculture (USDA). 2011. Conservation reserve program July 2011 monthly summary. USDA Farm Service Agency, Washington, D.C., USA. [online] URL: http://www.nrcs.usda.gov/Programs/CSP/

United States Department of Agriculture National Agricultural Statistics Service (USDA-NASS). 2007. Women farmers. USDA-NASS, Washington, D.C., USA. [online] URL: http://www.agcensus.usda.gov/Publications/2007/ Online_Highlights/Fact_Sheets/index.asp

United States Department of Agriculture National Agricultural Statistics Service (USDA-NASS). 2009. 2007 Census of agriculture. USDA-NASS, Washington, D.C., USA.

United States Department of Agriculture National Institute of Food and Agriculture (USDA-NIFA). 2006. Hispanic-Latino farmers and ranchers project. USDA-NIFA, Washington, D. C., USA. [online] URL: http://www.csrees.usda.gov/nea/ ag systems/in focus/smallfarms if hispanic farmers ranchers. $\underline{\mathrm{html}}$

United States Department of Agriculture Natural Resources Conservation Service (USDA-NRCS). 2009a. Conservation security program. USDA-NRCS, Washington, D.C., USA. [online] URL: http://www.nrcs.usda.gov/Programs/CSP/

United States Department of Agriculture Natural Resources Conservation Service (USDA-NRCS). 2009b. Environmental quality incentives. USDA-NRCS, Washington, D.C., USA. [online] URL: http://www.nrcs.usda.gov/Programs/CSP/

United States Department of Agriculture Natural Resources Conservation Service (USDA-NRCS). 2012. EQIP Organic Initiative. USDA-NRCS, Washington, D.C., USA. [online] URL: http://www.nrcs.usda.gov/wps/portal/nrcs/detail/national/ programs/financial/eqip/

Veteto, J., G. P. Nabhan, R. Fitzsimmons, K. Routson, and D. Walker. 2011. Place-based foods of Appalachia. Renewing America's food traditions. Gary Nabhan, Patagonia, Arizona, USA. [online] URL: http://garynabhan.com/pbf-pdf/AA\% 20APPALACHIA'S\%20PLACE-BASED FOODS.pdf 
Viva Farms. 2011. Welcome. [online] URL: http://www. vivafarms.org/

Walker, R. 2006. The conquest of bread. University of California Press, Berkeley, California, USA.

Warner, K. D. 2007. Agroecology in action: extending alternative agriculture through social networks. MIT Press, Cambridge, Massachusetts, USA.

Warner, K. D. 2008. Agroecology as participatory science: emerging alternatives to technology transfer extension practice. Science, Technology and Human Values 33:754. http://dx.doi.org/10.1177/0162243907309851

Wilgen, B. W., and H. C. Biggs. 2011. A critical assessment of adaptive ecosystem management in a large savanna protected area in South Africa. Biological Conservation, 144 (4): 1179-1187.

Wright, J. 2005. Discussion: policy implications of Cuba's achievements in sustaining its agriculture and food security base. Thesis, Wageningen University, Wageningen, The Netherlands.

Zezima, K. 2011. As farmers' markets go mainstream, some fear a glut. New York Times, 21 August. http://dx.doi. org/10.1016/S0013-9351(05)80002-7 